\title{
Herpes Simplex Virus 1 IgM Antibody Measurement
}

National Cancer Institute

\section{Source}

National Cancer Institute. Herpes Simplex Virus 1 IgM Antibody Measurement. NCI

Thesaurus. Code C98738.

The determination of the amount of herpes simplex virus $1 \mathrm{Ig} M$ antibody present in a sample. 